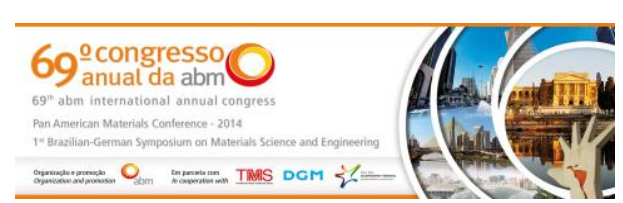

Tema: Metalurgia Física e Comportamento de Materiais em Temperaturas Elevadas

\title{
DEVELOPMENT OF X-80 HTP LINEPIPE STEEL OVER 40 YEARS ${ }^{*}$
}

John Malcolm Gray ${ }^{1}$

\begin{abstract}
Interest in X-80 linepipe steels emerged in the early 1980's and it was first used in 1985 by Ruhr Gas [1]. The early steels were extensions of conventional $\mathrm{Nb}-\mathrm{V}$ or $\mathrm{Nb}-$ Mo microalloyed X-70 steels but other alloying concepts emerged based on Nb-Mo-B alloying (NKSTAF [2] and ULCB [3]). The latter had acicular ferrite/bainitic microstructures and carbon contents below 0.05 percent. In parallel renewed interest developed in ultra low carbon (0.02 percent) higher niobium steels which had first been studied in 1962 [4]. Such steels exhibited excellent notch toughness when processed with high finish rolling temperatures $\left(>950^{\circ} \mathrm{C}\right)$ which made them suitable for processing on weak, older rolling mills. With time such steels, designated "High Temperature Processed", or HTP steels, were further optimized and produced in modern, very strong rolling mills due to their superior economy compared with traditional vanadium and molybdenum containing steels. The chronology of the HTP development is presented in the present paper. Full scale demonstration heats of a 0.06 percent carbon 0.10 percent niobium steel were produced by Bofors Steel Plant in 1972 and were converted from slabs to plates by nine different steel mills [5-7]. Commercial application in API Grade X-70 first occurred in Canada in 1974 [8,9] but the concept was only used sporadically after that until 1998 when it was applied for the API Grade X-70 Sour Service Cantarell Project [10] in Mexico. Soon thereafter, the El Paso Cheyenne Plains Project used a $0.05 \% \mathrm{C} 0.095 \% \mathrm{Nb} 0.27 \% \mathrm{Cr}$ variant of the HTP steel [10-12]. Nowadays the HTP concept is being utilized for construction of approximately $6000 \mathrm{~km}$ of 48" OD x $18.4 \mathrm{~mm}$ X-80 per year in China. The metallurgical principles and history of the development are presented in details in this paper.
\end{abstract}

Keywords: API X80, Acicular Ferrite/Bainite, Cantarell Project, High Temperature Processing (HTP).

1 M. Met, PhD, C. Eng, FASM, President, Microalloying Steel Institute, 5100 Westheimer, Houston, USA.

* Technical contribution to the 69 th $A B M$ International Annual Congress and to the ENEMET, July $21^{\text {st }}-25^{\text {th }}$, 2014, São Paulo, SP, Brazil. 


\section{METALLURGICAL BASIS}

The HTP concept relies on sequential effects of niobium which affect the response of the steel to reheating, hot rolling and subsequent cooling. The complex effects are remarkably complimentary and are not matched by any other single element, although other elements such as titanium may impart individual benefits. The metallurgical effects of niobium are discussed below:

(i) Niobium prevents austenite grain growth during reheating prior to rolling, Figure $1[13]$ and thereby facilitates the development and maintenance of a refined austenite microstructure during roughing, holding and final rolling.

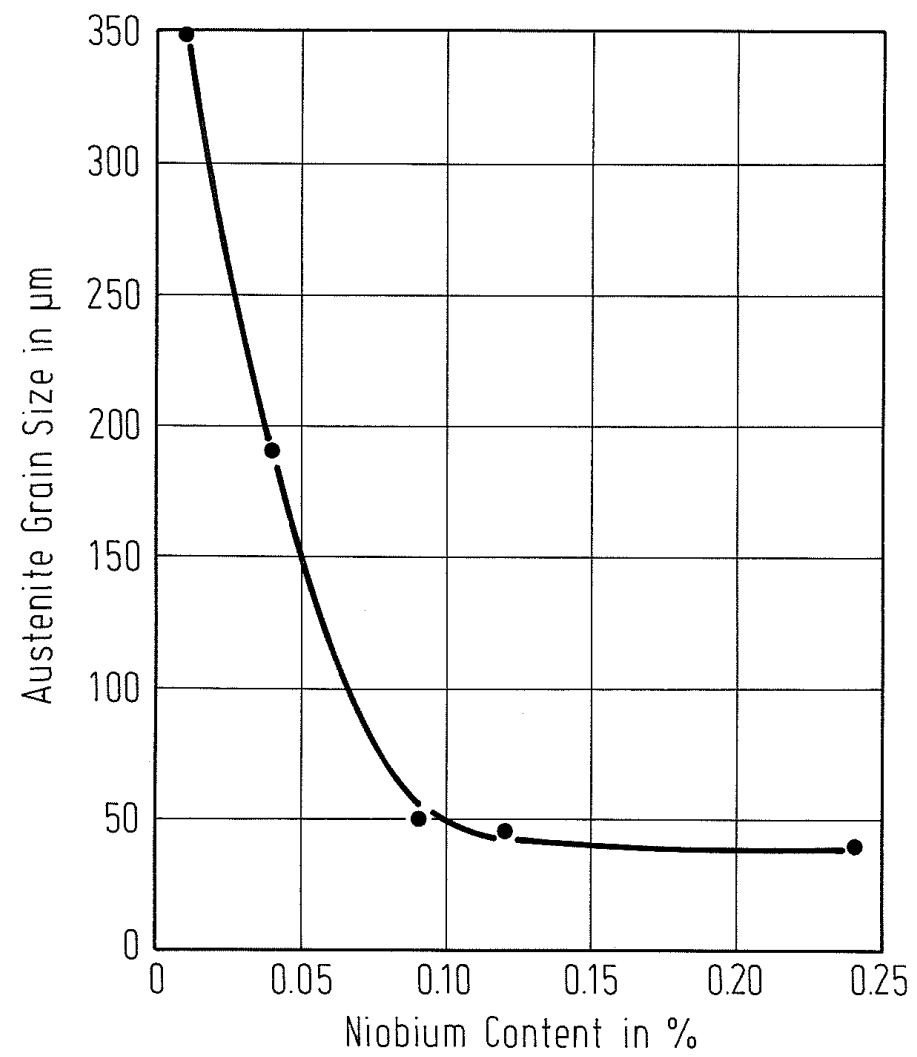

Figure 1. Effect of niobium content on austenite grain size at a soaking temperature of $1175^{\circ} \mathrm{C}$ for three hours [13].

(ii) Niobium in solution retards recovery at high temperatures and thereby facilitates strain accumulation necessary to produce recrystallization [14]. Niobium carbide undissolved at the reheating temperature also retards austenite grain growth at high temperatures.

(iii) Strain induced precipitation of niobium carbide occurs during finish rolling at temperatures below approximately $980^{\circ} \mathrm{C}$, depending on niobium and carbon content. This has a profound effect in retarding austenite recrystalization Figure 2 [15] and is the fundamental basis for controlled rolling [16].

* Technical contribution to the 69 th $A B M$ International Annual Congress and to the ENEMET, July $21^{\text {st }}-25^{\text {th }}$, 2014, São Paulo, SP, Brazil. 


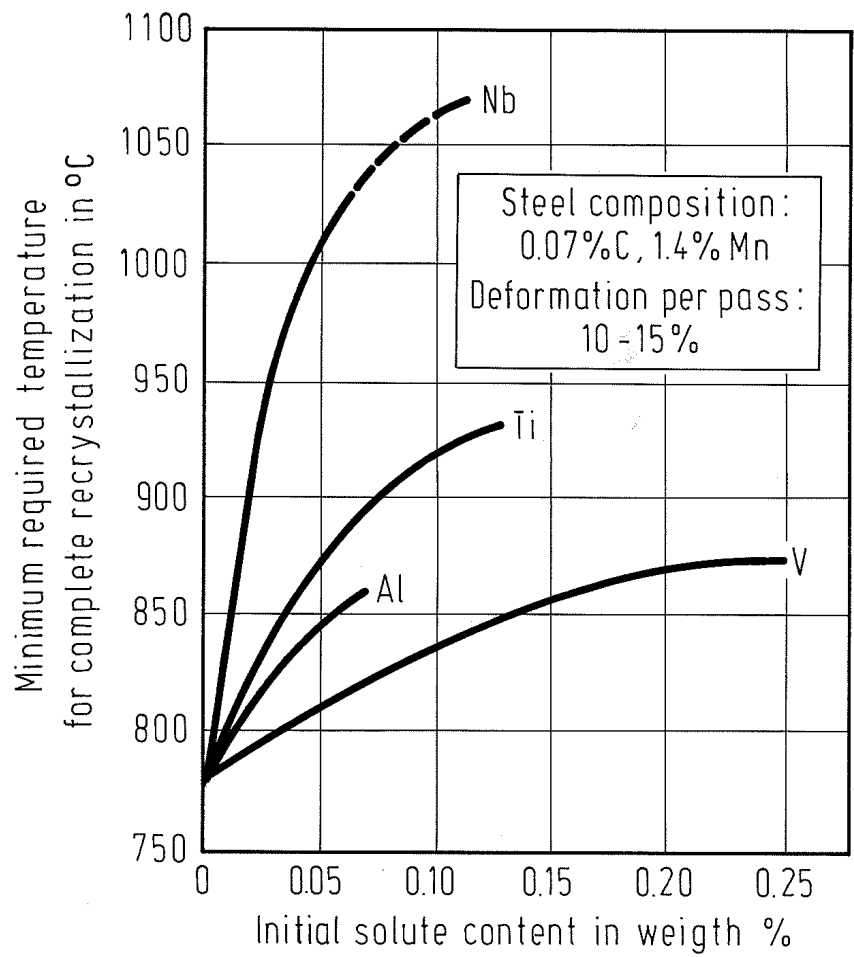

Figure 2. Retardation of recrystalization by microalloying elements [15].

(iv) Solute niobium retards the formation of polygonal ferrite $[17,18]$ and thereby lowers the austenite to ferrite transformation temperature, typically by approximately $100^{\circ} \mathrm{C}$, thereby favoring the formation of bainite over a wide range of cooling rates Figures 3 [19] and 4 [20].

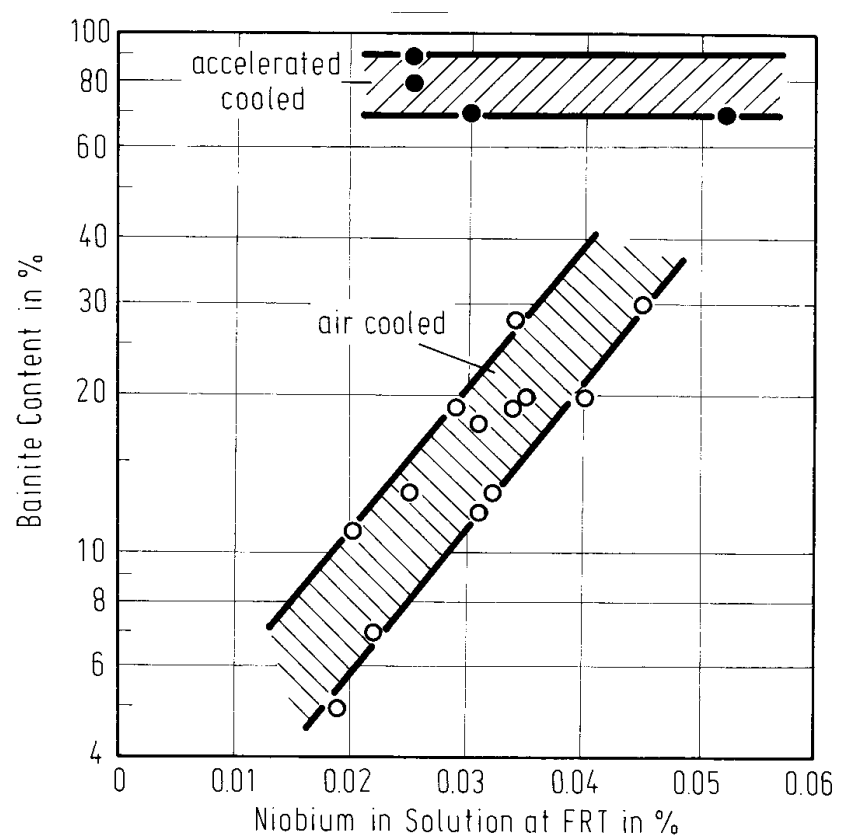

Figure 3. Influence of niobium in solid solution at the finish rolling temperature on the volume fraction of bainite in air cooled and accelerated cooled HTP plate [19].

* Technical contribution to the 69 ${ }^{\text {th }} A B M$ International Annual Congress and to the ENEMET, July $21^{\text {st }}-25^{\text {th }}, 2014$, São Paulo, SP, Brazil. 


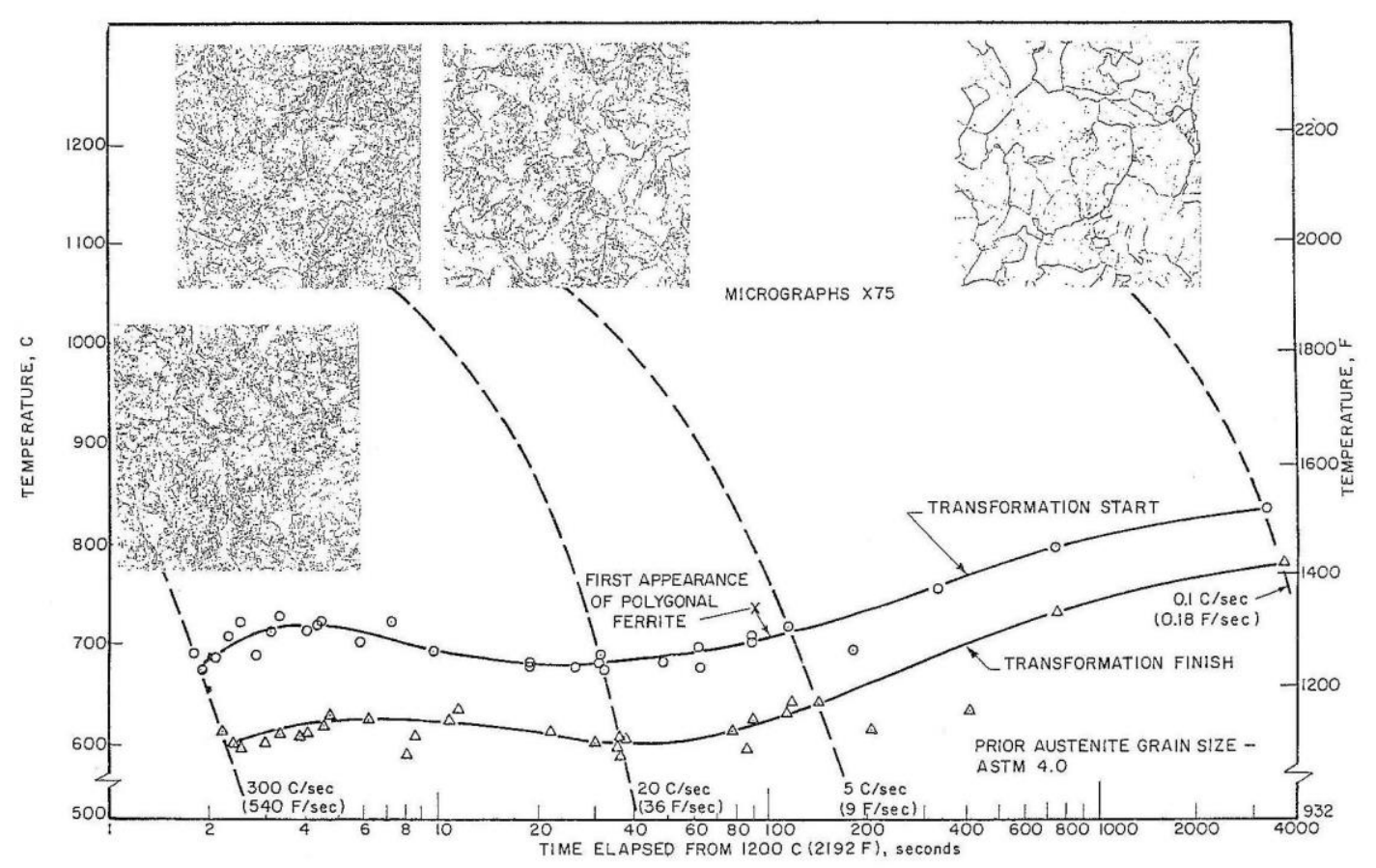

Figure 4. Continuous cooling transformation diagram for a $0.02 \% \mathrm{C} 0.49 \% \mathrm{Mn} 0.10 \% \mathrm{Nb}$ steel [20].

This effect is more pronounced in the presence of molybdenum [21,22] and boron [19] and is a fundamental building block for the bainitic/acicular ferrite linepipe steels referenced earlier [2,3].

(v) Niobium in solution at the time of transformation acts as described in (iv) above then subsequently precipitates as very fine niobium carbonitrides both during transformation and later in ferrite [23]. The magnitude of the effect is quantified in Figure 5 [13]. This precipitation hardening effect was discovered in the early 1960's [24] and provided the early stimulus for the development of microalloying technology.

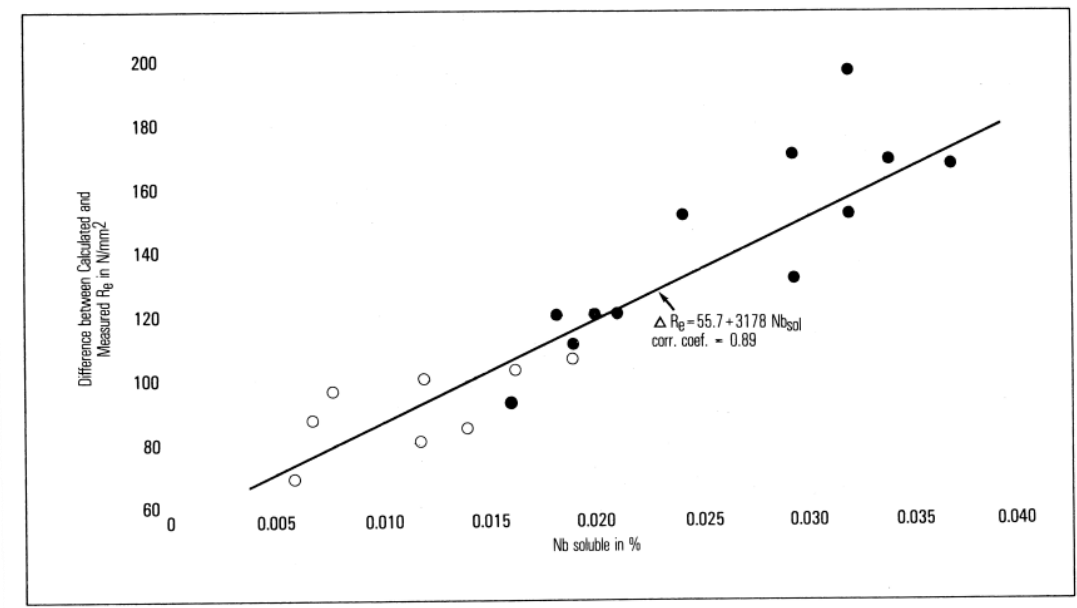

Figure 5. Correlation between soluble niobium content and yield strength increase [13].

(vi) Niobium retards austenite grain growth during high temperature heat treatments, hot bending and at the peak temperatures encountered during welding Figure 6 [25]. In the latter case contributions arise from Zener drag due to niobium carbide precipitates and possibly solute drag effects.

* Technical contribution to the 69 $9^{\text {th }} A B M$ International Annual Congress and to the ENEMET, July $21^{\text {st }}-25^{\text {th }}, 2014$, São Paulo, SP, Brazil. 

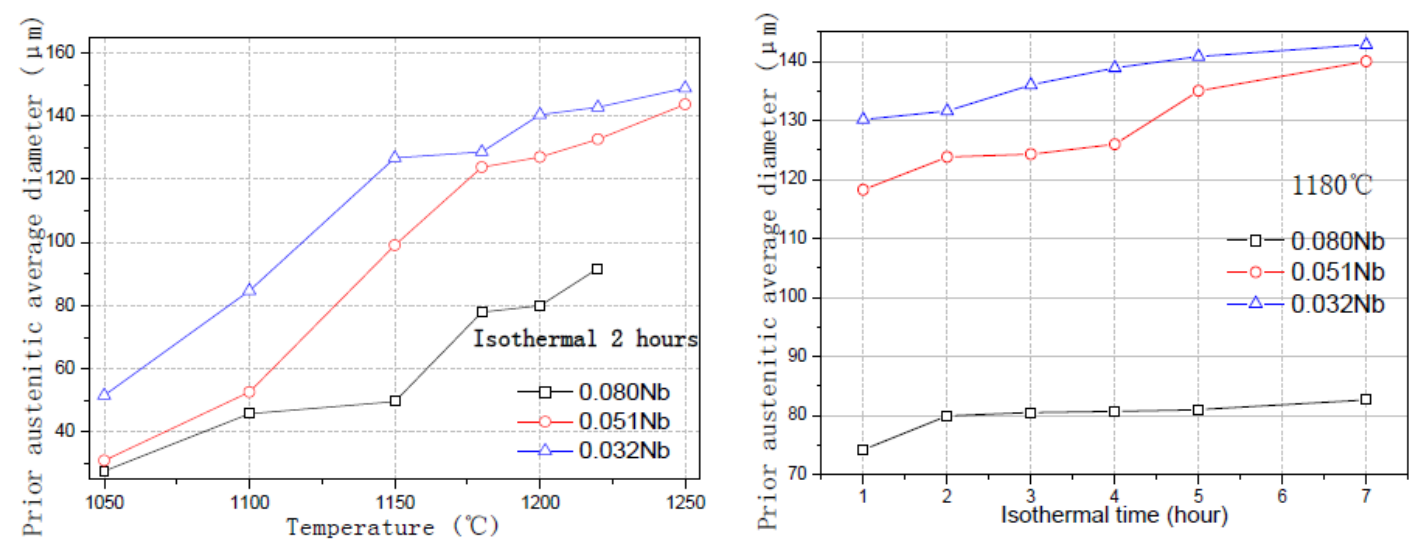

Figure 6. Effect of niobium in retarding austenite grain growth at high temperatures [25].

That fine ferrite grain sizes and thus good notch toughness could be achieved at high finish rolling temperatures $\left(>1000^{\circ} \mathrm{C}\right)$ was documented as early as 1972 [26] and elegantly demonstrated in the research of Kozasu et al Figure 7 circa 1974 [27]. It is now known that all the above metallurgical processes are operating sequentially in one way or another during heating and thermomechanical rolling. The magnitude of the solute niobium effects depends on carbon and nitrogen contents and the strain history and is difficult to maximize when heavy deformation is applied in the 900$950^{\circ} \mathrm{C}$ temperature range. This can be a serious handicap when Steckel Mill processing is involved [28].

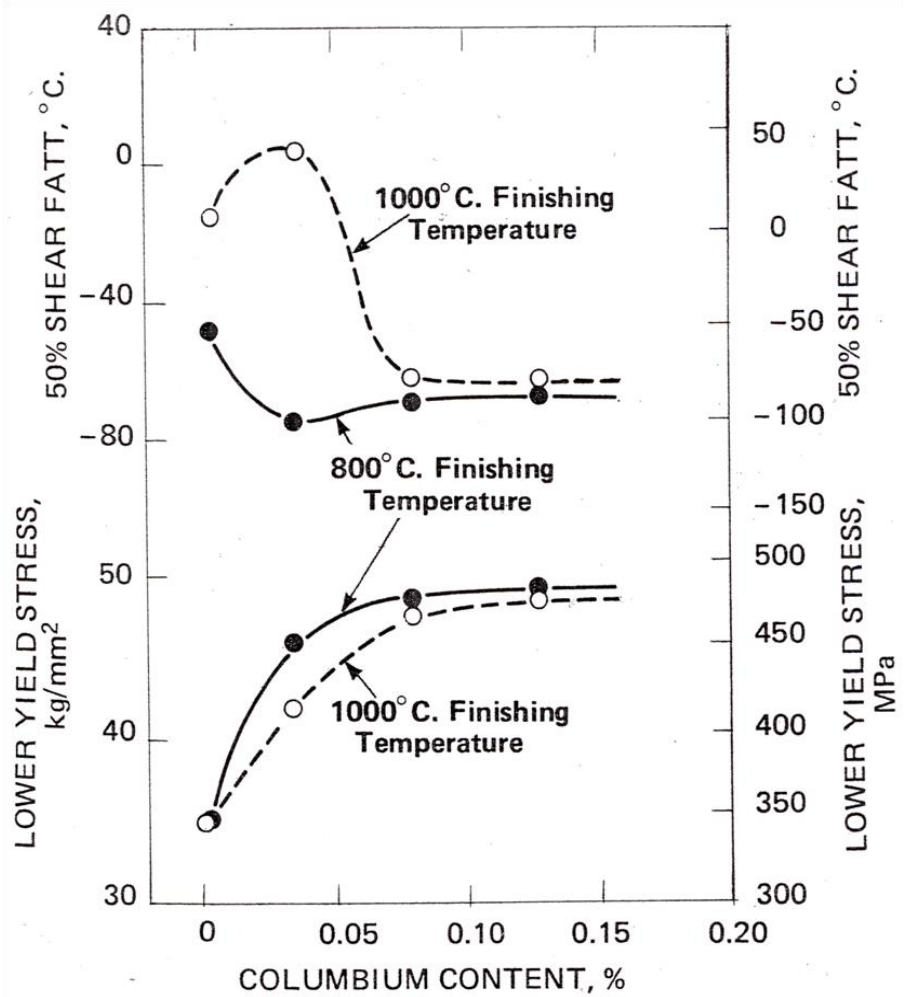

Figure 7. Effect of niobium (columbium) content and finish rolling temperature on yield strength and notch toughness [27].

* Technical contribution to the 69 th $A B M$ International Annual Congress and to the ENEMET, July $21^{\text {st }}-25^{\text {th }}$, 2014, São Paulo, SP, Brazil. 


\section{PRACTICAL RESULTS AND APPLICATION}

The effect of niobium content and finish rolling on Fracture Appearance Rolling Temperature (FATT) for $20 \mathrm{~mm}$ thick 0.06 percent carbon 1.55 manganese plate is presented in Figure 8 [29]. Application of higher niobium contents has allowed production of linepipe with excellent notch toughness even during the inexorable trend toward higher strengths Figure 9. Thus DWTT Shear Area Transition Temperatures of $-50^{\circ} \mathrm{C}$ combined with yield strength of $80 \mathrm{ksi}$ (550 MPa) can be achieved in plates up to $33.7 \mathrm{~mm}[30]$.

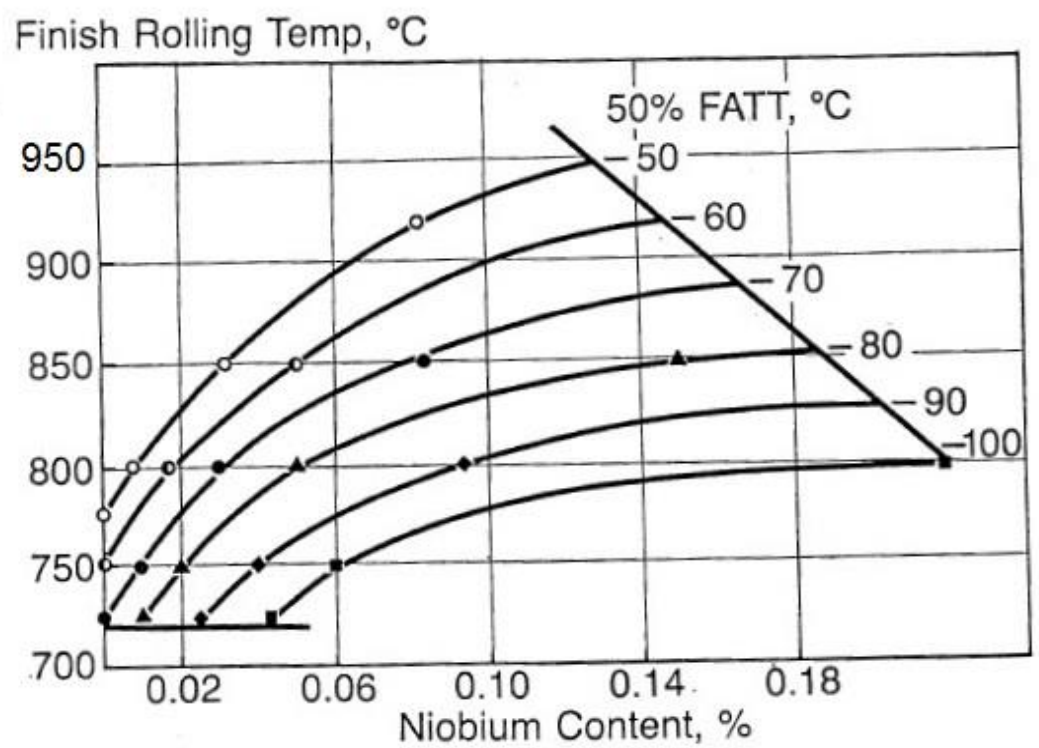

Figure 8. Effect of niobium content and finish rolling temperature on Fracture Appearance Transition Temperature (FATT) for $20 \mathrm{~mm}$ plate [29].

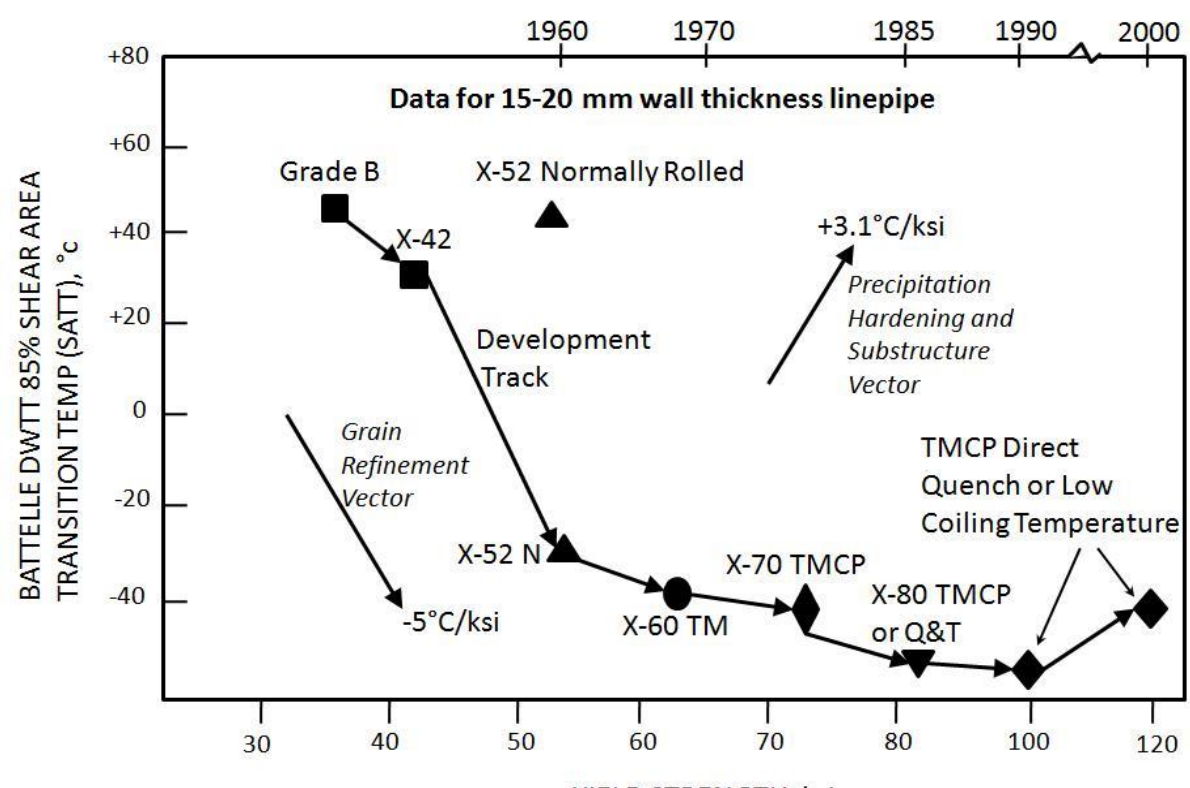

YIELD STRENGTH, ksi

Figure 9. Progress of development showing simultaneous increase in toughness with strength and passage of time [29].

* Technical contribution to the 69 th $A B M$ International Annual Congress and to the ENEMET, July $21^{\text {st }}-25^{\text {th }}$, 2014, São Paulo, SP, Brazil. 
Apart from the benefits of rolling the HTP niobium steel at higher temperatures and the consequent reduction in rolling loads, it has been found that the operating window with respect to finish cooling (water stop) temperature during TMCP processing is much larger than the corresponding window for conventional $\mathrm{Nb}-\mathrm{V}$ microalloyed plate, Figures 10 and 11 [31].

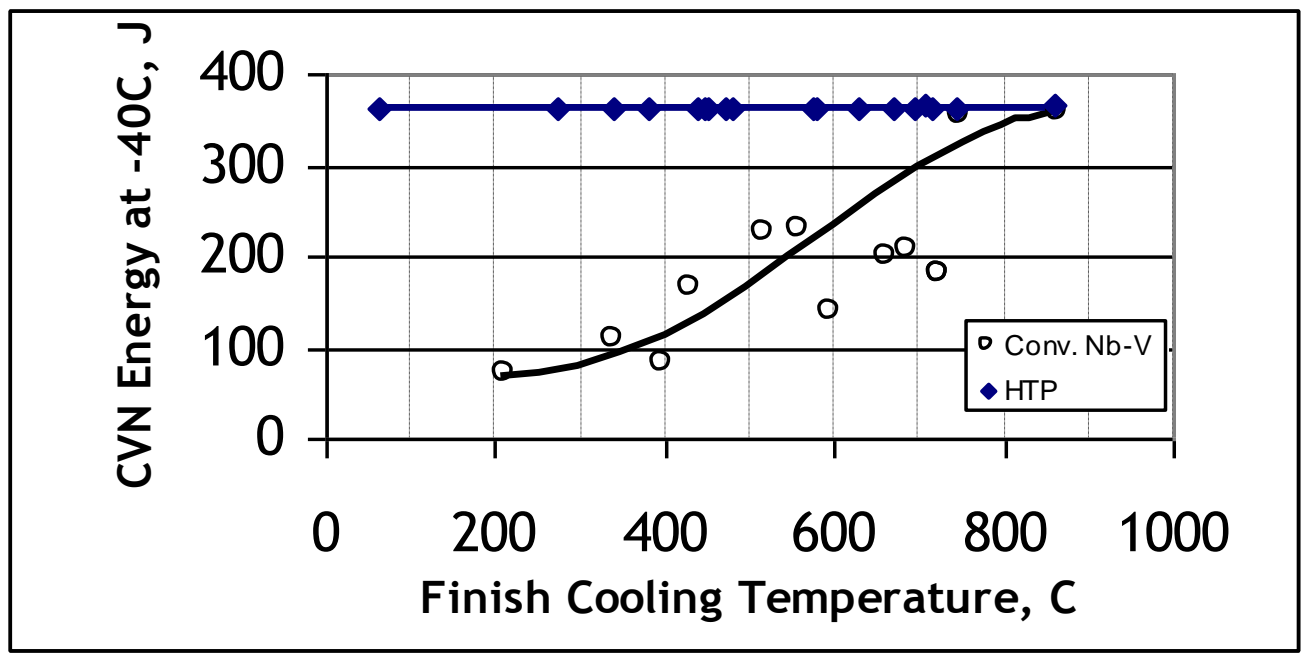

Figure 10. Wide processing window for Charpy energy of $0.03 \% \mathrm{C} 1.60 \% \mathrm{Mn} 0.095 \% \mathrm{Nb} 0.27 \% \mathrm{Cr} 22$ $\mathrm{mm}$ plates cooled at $6^{\circ} \mathrm{C} / \mathrm{s}[31]$.

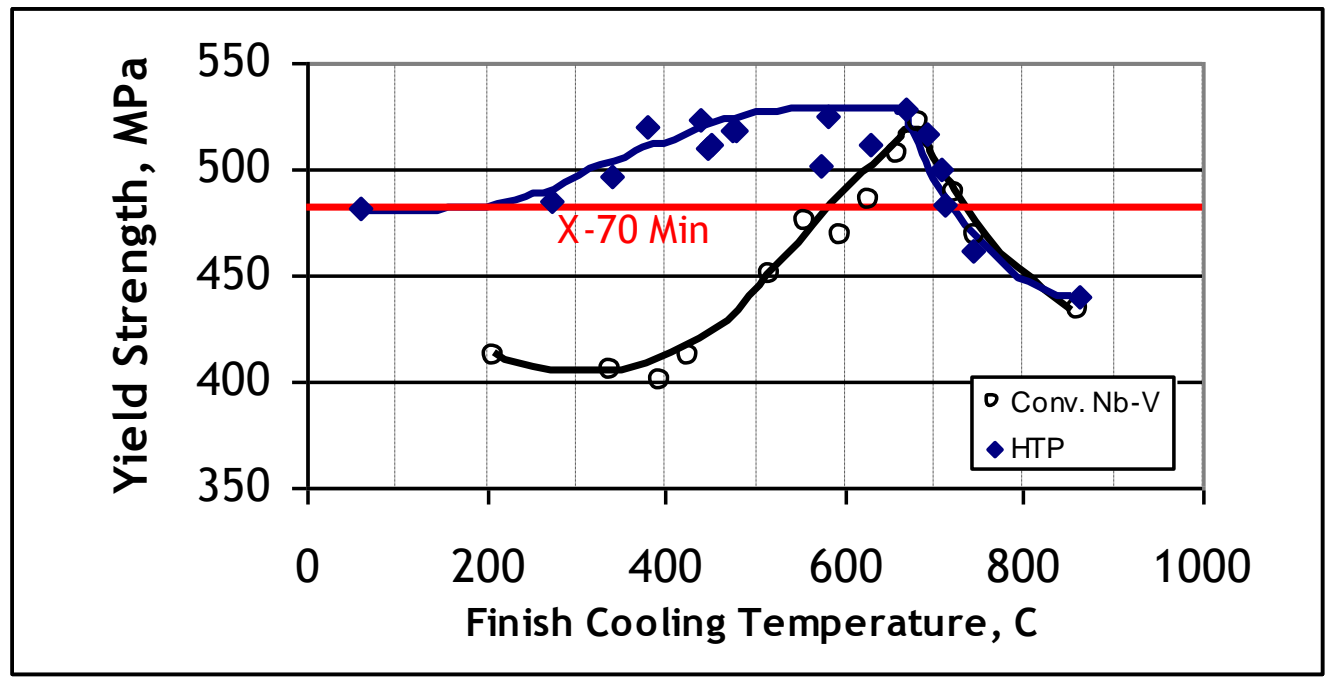

Figure 11. Wide processing window for yield strength of $0.03 \% \mathrm{C} 1.6 \% \mathrm{Mn} 0.095 \% \mathrm{Nb} 0.27 \% \mathrm{Cr} 22 \mathrm{~mm}$ plates cooled at $6^{\circ} \mathrm{C} / \mathrm{s}$ [31].

This has stimulated widespread adaption of the HTP technology in China since 2005 Figure 12 when the Second-West East Pipeline was announced. The project consumed approximately 2 million tons of $18.4 \mathrm{~mm} \mathrm{48"} \mathrm{OD} \mathrm{X-80} \mathrm{linepipe,} \mathrm{with}$ subsequent similar consumption for the Third West-East Pipeline which is about 70 percent complete. These projects have a dominant effect on the logarithmic growth of installations worldwide, Figure 13.

* Technical contribution to the 69 th $A B M$ International Annual Congress and to the ENEMET, July $21^{\text {st }}-25^{\text {th }}, 2014$, São Paulo, SP, Brazil. 

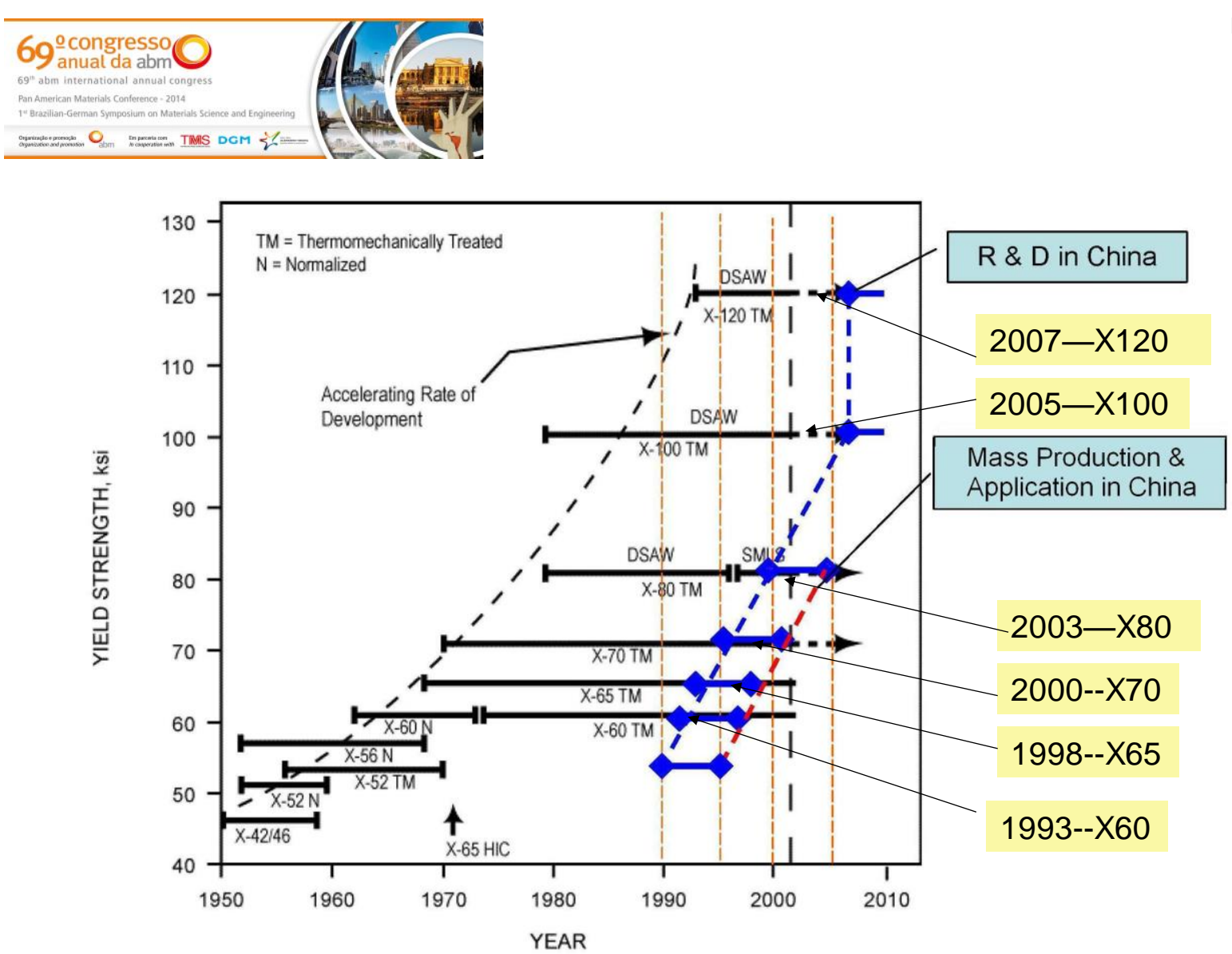

Figure 12. Rapid rate of adoption of API Grade X-80 linepipe in China.

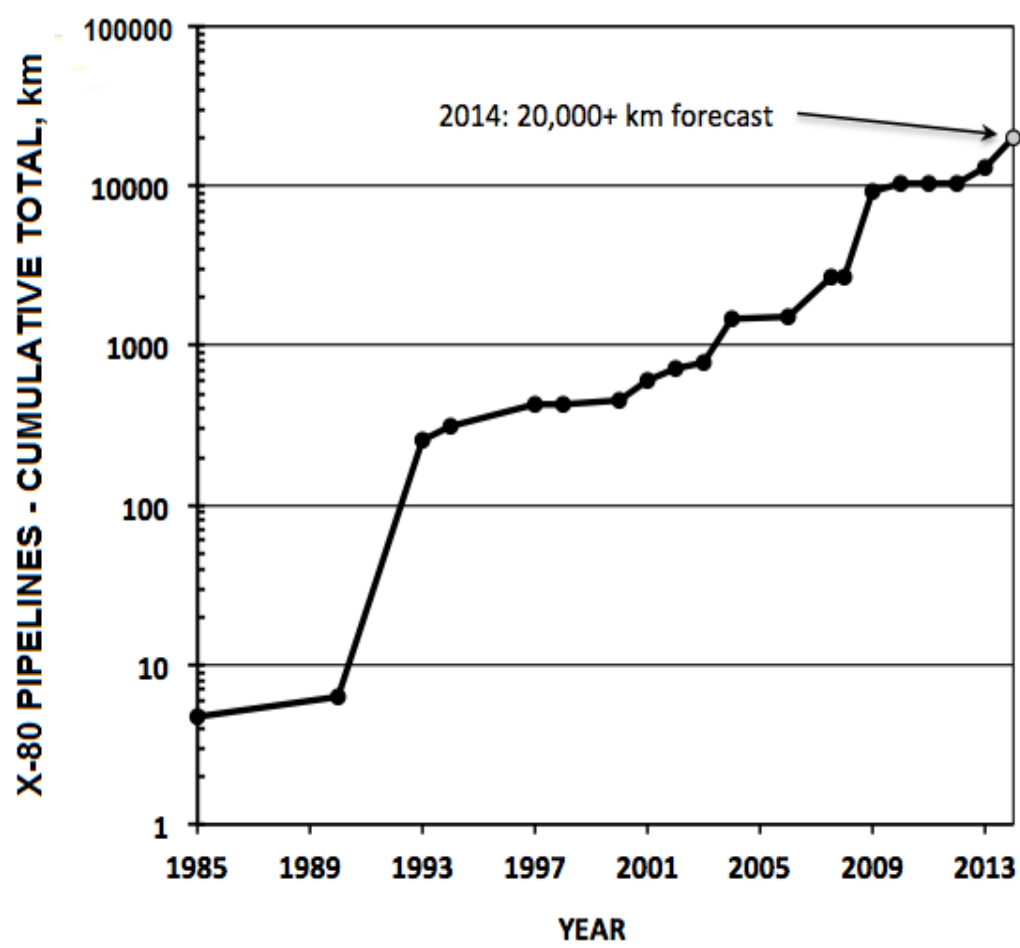

Figure 13. Progress in adopting $X-80$ steel.

A final benefit of the use of higher finishing temperatures is the minimization of the harmful $\{100\}$ rotated cube textures, that cause fracture surface separations Figure 14 [32] and poor through thickness ductility as defined by $Z$ direction Charpy FATT and Lankford plastic strain ration resistance to thinning Figure 15 [32] which plague efforts to predict ductile fracture arrest in higher strength steels (API Grade X80) and above). These efforts are currently being elucidated in several fracture propagation studies.

* Technical contribution to the $69^{\text {th }} A B M$ International Annual Congress and to the ENEMET, July $21^{\text {st }}-25^{\text {th }}, 2014$, São Paulo, SP, Brazil. 


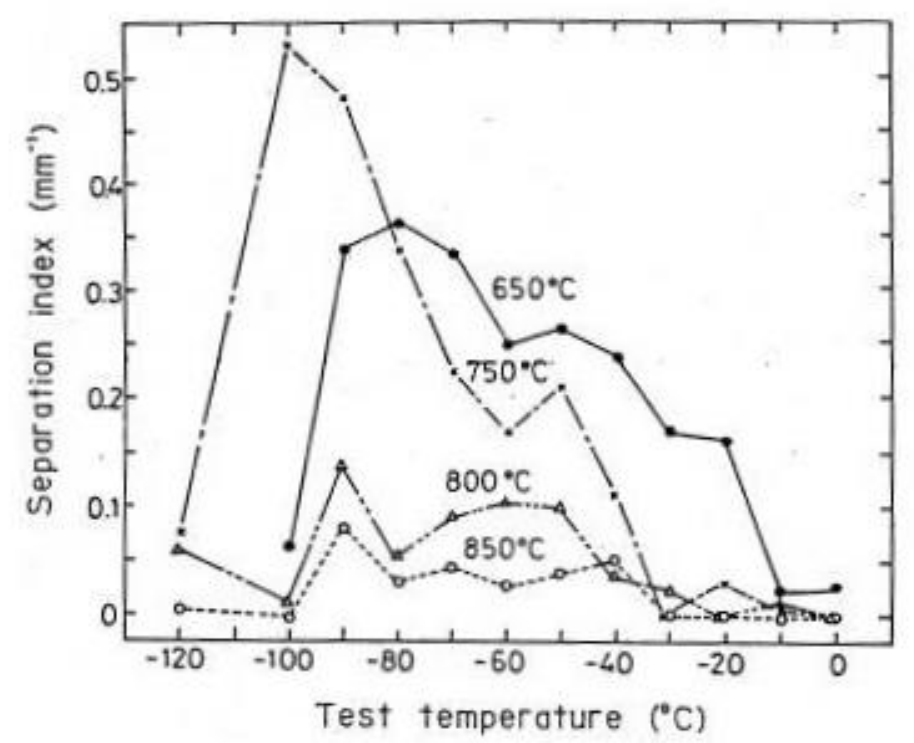

Figure 14. Effect of Finish Rolling Temperature on separation index [32].

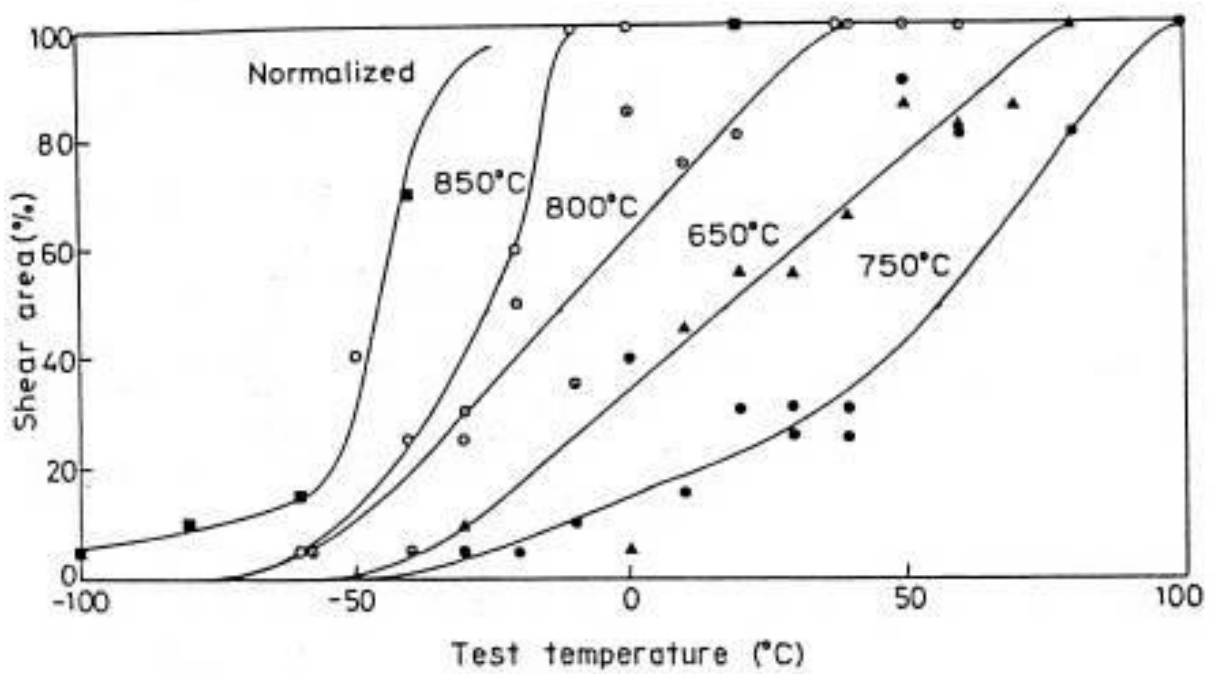

Figure 15. Effect of Finish Rolling Temperature on Z direction Charpy V-notch FATT [32].

\section{CONCLUSIONS}

- By end of 2014 there will be $20,000 \mathrm{~km}$ of $X-80$ linepipe installed.

- 65-70 percent if expected use the HTP concept.

- Fracture arrest behaviour of steels rolled with high finishing is superior to steels with strong $\{100\}$ textures developed during low temperature $<700^{\circ} \mathrm{C}$ finishing.

\section{REFERENCES}

1 Hillenbrand HG, Heckmann CJ, Niederhoff K A. X80 Line pipe for large diameter high strength pipelines. In: API X-80 Pipeline Cost Workshop; 20 Oct. 2002, Hobart, Australia. 2002.

2 Osuka T, Tsukada K, Watanabe T. Super Tough Acicular Ferrite X-70 Steel Linepipe (NK STAF-70). NKK Technical Report. September; 1981.

* Technical contribution to the $69^{\text {th }} A B M$ International Annual Congress and to the ENEMET, July $21^{\text {st }}-25^{\text {th }}, 2014$, São Paulo, SP, Brazil. 


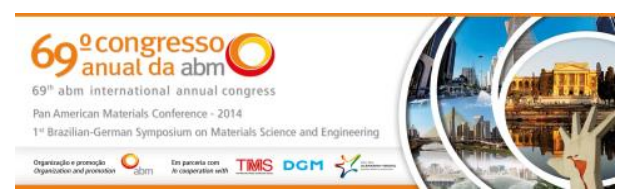

3 Nakasugi H, H Matsuda, H Tamehiro. Development of Controlled-Rolled Ultra Low Carbon Bainitic Steel for Large Diameter Line Pipe. In: Alloys for the 80's; June 17 and 18, 1980; Ann Arbor, USA.

4 Gray JM. Carbide Precipitation and Yielding in Mild Steels Containing Niobium [PhD thesis]. University of Sheffield; July 1965.

5 Gray M, Wilson WG. Effect of Processing Variables on the Properties of a Low-Carbon Columbium Steel Proposed for Arctic Pipelines. In: Proceedings of the $14^{\text {th }}$ Mechanical Working and Steel Processing Conference; January 29, 1972; Chicago, USA. Volume X; 1972.

6 Gray JM, Wilson WG. Molycorp Develops X-80 Pipeline Steel. Pipeline and Gas Journal. 1972;199(14):50.

7 Gray JM, Wilson WG. Evaluation of an X-80 Arctic Pipeline Steel. In: ASME, Proceedings of the Petroleum Mechanical Engineering Conference; September 16-20, 1973; Los Angeles, USA. ASME; 1974.

8 Shaughnessy RN, Witty RW. Canadian Patent Number 966702, April, 1975.

9 Hamre EC, Gilroy SAM. Properties of Acicular-Ferrite Steel for Large - Diameter Line Pipe. In: Proceedings of the $75^{\text {th }}$ Microalloying; Oct. 1-3, 1975; Washington, USA.

10 Mendoza L, Cepeda VC. Experience with Low Carbon HSLA Steel containing 0.06 to 0.10 percent Niobium. In: Araxa HTP Symposium; October 2003; Araxa, Brazil. Pemex X-70 Cantarell Project.

11 Hulka K, Bordignon P, Gray JM. Summary of the Araxa HTP Symposium; October 2003; Araxa, Brazil.

12 Fazackerley WJ, Manuel PA, Christensen L. First X-80 HSLA Pipeline in the USA. In: Proceedings of the International Symposium on Microalloyed Steels for the Oil and Gas Industry; 23-26 Jan. 2006; Araxa, Brazil. TMS; 2006.

13 Heisterkamp F, Hulka K. Low-Carbon Manganese-Nickel-Niobium Steel [Niobium Technical Report]. NBTR-04/83. CBMM; Nov. 1983.

14 Zurob HS. Zhu G, Subramanian SV, Purdy GR, Hutchinson CR, Brechet Y. Analysis of the effect of manganese on the recrystalization kinetics of high niobium steel: an example of physically-based alloy design. ISIJ International. 2005;45(5):713-722.

15 Cuddy JL. The Effect of Microalloy Concentration on the Recrystalization of Austenite During Hot Deformation. In: Proceedings of the Thermomechanical Processing of Microalloyed Austenite; 17-19 Aug. 1981; Pittsburgh, USA. AIME/TMS; 1981. p.129-140.

16 Irani JJ, Burton D, Jones JD, Rothwell AB. Beneficial Effects of Controlled Rolling in the Process of Structural Steels Strong Tough Structural Steels Scarboro. ISI Special Publication. 1967; April 4-6; No. 104.

17 Gray JM. The Effect of Niobium (Columbium) on Transformation and Precipitation Processes in High-Strength Low Alloy Steels. In: 73 ISI Conference entitled Heat Treatment; Dec. 12-13, 1973; London, UK.

18 Ronn L. Metallurgical Engineer Thesis. The Royal Institute of Technology Thesis; 1963.

19 Hulka K, Gray JM. High Temperature Processing of Line Pipe Steels. In: Proceedings of the International Symposium, Niobium 2001; 2001; Orlando, USA.

20 Gray JM, Wilkening W, Russell G. Transformation Characteristics of Very-Low Carbon Steel. US Steel Report 89.002-015(3); May 15, 1969.

21 Coldren AP, Cryderman RL, Semchyshen M. Strength and Impact Properties of LowCarbon Structural Steels Containing Molybdenum. In: Climax Molybdenum Symposium on Steel Strengthening Mechanisms; May 1969; Zurich, Swiss.

22 Cryderman RL, Coldren AP, Smith VE, Mihelich JL. The Development of a High-Strength Hot-Rolled Mn-Mo-Cb Steel. In: $14^{\text {th }}$ Mechanical Working and Steel Processing Conference; 19 Jan. 1972; Chicago, USA.

23 Gray JM. Carbide Precipitation and Yielding in Mild Steel Containing Niobium [PhD thesis]. University of Sheffield; July 1965.

24 Morrison WB. The Influence of Small Niobium Additions on the Properties of CarbonManganese Steels. J. Iron Steel Inst. 1963;201:317.

* Technical contribution to the 69 $9^{\text {th }}$ ABM International Annual Congress and to the ENEMET, July $21^{\text {st }}-25^{\text {th }}$, 2014, São Paulo, SP, Brazil. 
25 Qingyou L. Weldability of High Grade Pipeline Steels [private communication]. Beijing: CISRI; March 2014.

26 Gray JM. Columbium as a Grain Refiner in Hot-Rolled Steels. In: Proceedings of the AIME Symposium on Processing and Properties of Low-Carbon Steels; October 18-19, 1972; Cleveland, USA. AIME; 1972.

27 Kozasu I, Ouchi C, Sampei T, Okita T. Hot Rolling as High-Temperature ThermoMechanical Process. Microalloying's 75 Conference Proceedings; October 1-3, 1975; Washington, USA. p.120-135.

28 Collins LE, Baragar DL, Bowker JT, Kostic MM, Subramanian SV. Steckel Mill Process Optimization for Production of X-70 and X-80 Gas Transmission Linepipe. In: Proceedings of the Microalloying '95 Conference; June 11-14, 1995; Pittsburgh, USA. p.141-147.

29 Heisterkamp F, Bergmann B, Stuart H, Chaussy L. Developments in Niobium Steels for Linepipe Applications. In: Steels for Line Pipe and Pipeline Fittings; 21-23 Oct. 1981; London, UK.

30 Konygin D, Korchagin A. SeverStal: Development of Hot-Rolling Technology for Large Diameter Pipe Manufacture. In: SeverStal Energy Industry Conference; May 31-Jun. 02, 2012; St. Petersburg, Russia.

31 Lin M, Bodnar RL. Effect of Composition and Processing Conditions on a $0.03 \% \mathrm{C}$ $0.095 \% \mathrm{Nb}$ X-70 Linepipe Steel. In: ISS. $40^{\text {th }}$ Mechanical Working and Steel Processing Conference; 1998; Warrendale, USA.

32 Inagaki H. Effect of Crystallographic Texture on the Separation Behaviour of ControlRolled Low Carbon Steel [technical Bulletin]. Kawasaki-ku: NKK Technical Research Center; circa 1979.

* Technical contribution to the 69 th $A B M$ International Annual Congress and to the ENEMET, July $21^{\text {st }}-25^{\text {th }}, 2014$, São Paulo, SP, Brazil. 